\title{
Antigenotoxic and antimutagenic effects of Schinus terebinthifolius Raddi in Allium cepa and Swiss mice: A comparative study
}

\author{
L.E.S. Fedel-Miyasato ${ }^{1,2}$, A.S.N. Formagio ${ }^{3}$, S.A. Auharek ${ }^{4,5}$, \\ C.A.L. Kassuya ${ }^{6}$, S.D. Navarro ${ }^{1,2}$, A.L. Cunha-Laura ${ }^{4}$, \\ A.C.D. Monreal $^{4}$, M.C. Vieira ${ }^{3}$ and R.J. Oliveira ${ }^{1,2,5}$ \\ ${ }^{1}$ Programa de Mestrado em Farmácia, \\ Centro de Ciências Biológicas e da Saúde, \\ Universidade Federal de Mato Grosso do Sul, Campo Grande, MS, Brasil \\ ${ }^{2}$ Centro de Estudos em Células Tronco, \\ Terapia Celular e Genética Toxicológica, Núcleo de Hospital Universitário, \\ Universidade Federal de Mato Grosso do Sul, Campo Grande, MS, Brasil \\ ${ }^{3}$ Faculdade de Ciências Agrárias, Universidade Federal da Grande Dourados, \\ Dourados, MS, Brasil \\ ${ }^{4}$ Centro de Ciências Biológicas e da Saúde, \\ Universidade Federal de Mato Grosso do Sul, Campo Grande, MS, Brasil \\ ${ }^{5}$ Programa de Pós-Graduação em Saúde e Desenvolvimento na Região \\ Centro-Oeste, Faculdade de Medicina "Dr. Hélio Mandetta", \\ Universidade Federal de Mato Grosso do Sul, Campo Grande, MS, Brasil \\ ${ }^{6}$ Faculdade de Ciências da Saúde, Universidade Federal da Grande Dourados, \\ Dourados, MS, Brasil \\ Corresponding author: R.J. Oliveira \\ E-mail: rodrigo.oliveira@ufms.br
}

Genet. Mol. Res. 13 (2): 3411-3425 (2014)

Received June 25, 2013

Accepted October 29, 2013

Published April 30, 2014

DOI http://dx.doi.org/10.4238/2014.April.30.2

ABSTRACT. It is estimated that $60 \%$ of anticancer drugs are derived directly or indirectly from medicinal plants. Schinus terebinthifolius Raddi (Anacardiaceae) is traditionally used in Brazilian medicine to treat 
inflammation, ulcers, and tumors. Because of the need to identify new antimutagenic agents and to determine their mechanism of action, this study evaluated the chemopreventive activity of the methanolic extract from leaves of S. terebinthifolius (MEST) in Allium cepa cells and in Swiss mice analyzing different protocols of MEST in association with DNA-damaging agents. The antigenotoxic and antimutagenic aspects in peripheral blood were evaluated using the comet and micronucleus assays, respectively. The percentage of damage reduction was used to compare the A. серa and mice results. Our results showed for the first time that MEST can act as a chemopreventive compound that promotes cellular genome integrity by desmutagenic and bioantimutagenic activities in vegetal and animal models. This finding may therefore have therapeutic applications that can indirectly correlate to the prevention and/or treatment of the degenerative diseases such as cancer.

Keywords: Alliumcepatest; Cometassay; Micronucleus; Chemoprevention

\section{INTRODUCTION}

Schinus terebinthifolius Raddi (Anacardiaceae), popularly known as aroeirinha, aroeira-vermelha, or Brazilian pepper, is a native plant from South America that can be found in different states of Brazil (Corrêa, 1974). In folk medicine, it is used to treat wounds and ulcers of skin and mucous membranes, tumors, diarrhea, arthritis, and infections of the urinary and respiratory systems (Morton, 1978). Some studies have shown that the medicinal properties of S. terebinthifolius are related to the high content of phenolic derivatives such as gallic acid, methyl gallate, tannins, and flavonoids that are responsible for S. terebinthifolius antioxidant and antitumor activities (Queires et al., 2006; Ceruks et al., 2007; de Mesquita et al., 2009; Santana et al., 2012). Moreover, S. terebinthifolius was included in Brazilian Pharmacopeia (Brandão et al., 2006).

It is well established in the literature that an increased cancer occurrence may be correlated with an increased frequency of DNA damage resulting from human exposure to xenobiotic agents. In general, DNA lesions can be (I) genotoxic, which refers to predominantly molecular damage such as double-strand breaks, crosslinks, base excision, and alkalilabile lesions that can be corrected by intracellular repair; or (II) mutagenic, which refers to irreversible damage that settles permanently in DNA derived from molecular changes such as clastogenic or aneugenic lesions (Dearfield et al., 2002; Lucio Neto, 2011). In this sense, identifying antimutagenic compounds capable of favoring the intracellular mechanisms of repair and decreasing the frequency of mutations are of great value to protect future generations from diseases.

Medicinal plants are important antimutagenic and chemopreventive agents capable of preventing and/or repairing genomic changes (Malini et al., 2010; de Carvalho et al., 2011). It is estimated that $60 \%$ of anticancer drugs are derived directly or indirectly from medicinal plants (WHO, 2011), which explains the large amount of research that aims to evaluate biological activities that demonstrate the balance and equilibrium of natural defenses through the action of antioxidants in modulating genomic repair (de Mesquita et al., 2009; Malini et al., 
2010). Thus, this study aimed to evaluate the effects of the methanolic extract from leaves of S. terebinthifolius (MEST) in the prevention and/or repair of genotoxic and mutagenic lesions as well as describe the mechanisms of action of MEST in Allium cepa and Swiss mice and compare the two biological models.

\section{MATERIAL AND METHODS}

\section{Plant material and extract}

The leaves of $S$. terebinthifolius were collected in Dourados, Mato Grosso do Sul State, Brazil in March 2012. A voucher specimen was identified by Maria do Carmo Vieira and deposited (No. 4602) in the herbarium of Universidade Federal da Grande Dourados (UFGD). The dried and ground leaves $(480 \mathrm{~g})$ were subjected to exhaustive maceration in 95\% methanol at room temperature. The solvent was evaporated in vacuo on a rotary evaporator and lyophilized. This procedure resulted in a methanolic extract (38 g) with a greenish color.

The MEST was diluted in $1 \%$ methanol in water and used at concentrations of 16.8 , 33.6, and $50.4 \mathrm{mg} / \mathrm{L}$ for Allium cepa studies. This assay was used to screen for mutagenic activity and antimutagenic activity and to describe the extract antimutagenic mode of action. Based on our results, an appropriate dose for the animal model (mice) was determined. Thus, the exposed mice group received $16.8 \mathrm{mg} / \mathrm{kg}$ MEST diluted in $1 \%$ methanol by gavage.

\section{Determination of total phenols}

In order to determine the total phenols of the MEST, the method of Folin-Ciocalteu was used (Meda et al., 2005). To each $100 \mu \mathrm{L}$ sample, $1.5 \mathrm{~mL} \mathrm{2 \%}$ aqueous sodium carbonate, $0.5 \mathrm{~mL}$ of Folin-Ciocalteu reagent $(1: 10 \mathrm{v} / \mathrm{v})$, and $1 \mathrm{~mL}$ distilled water were added and reacted for $30 \mathrm{~min}$. The samples were analyzed by a spectrophotometer at a wavelength of $760 \mathrm{~nm}$. The same procedure was used to analyze blank, substituting $100 \mu \mathrm{L}$ sample per 100 $\mu \mathrm{L}$ methanol (Djeridane et al., 2006). To calculate the concentration of phenols, an analytical curve was prepared $(1.0,5.0,10.0,15.0,30.0$, and $40.0 \mu \mathrm{g})$ using gallic acid as a standard, and the absorbance of each standard was read. The experimental procedure was performed with the same standard that was used for samples. With these data, linear regression was performed and the equation of the line was obtained using the data from the real samples. The results were expressed as mg gallic acid equivalent per $g$ extract. The equation for the gallic acid curve was $\mathrm{y}=6.5277 \mathrm{x}+0.0618$, with a correlation coefficient of $\mathrm{R}=0.9985$. All tests were performed in triplicate.

\section{Determination of total flavonoids}

To determine the level of flavonoids, $500 \mu \mathrm{L}$ sample was mixed with $1.50 \mathrm{~mL} 95 \%$ ethanol, $0.10 \mathrm{~mL} 10 \%$ aluminum chloride $\left(\mathrm{AlCl}_{3} \times 6 \mathrm{H}_{2} \mathrm{O}\right), 0.10 \mathrm{~mL} 1 \mathrm{M}$ sodium acetate (Na$\mathrm{C}_{2} \mathrm{H}_{3} \mathrm{O}_{2} \times 3 \mathrm{H}_{2} \mathrm{O}$ ), and $2.80 \mathrm{~mL}$ distilled water. The tubes were kept at room temperature for $40 \mathrm{~min}$. The optical density was measured at $415 \mathrm{~nm}$ using a spectrophotometer. The same procedure was employed to analyze the blank (Lin and Tang, 2007). To calculate the concentration of flavonoids, an analytical curve was prepared $(2.5,5.0,10.0,20.0,25.0,50.0,100.0$, 
and $125.0 \mathrm{mg}$ ) using quercetin as the standard. The linear regression model was used to obtain the line equation. From these data, the experimental samples were calculated. The result was expressed in milligrams quercetin equivalents per gram extract. The equation of the quercetin curve was $\mathrm{y}=613.177 \mathrm{x}+0.0162$, with a correlation coefficient of $\mathrm{R}=0.9921$. All tests were performed in triplicate.

\section{DNA-damaging agents}

We used methyl methanesulfonate (MMS) to induce DNA damage in meristematic cells of $A$. cepa. MMS is an alkylating agent with direct activity at a concentration of 10 mg/L (Sigma-Aldrich; CAS 66-27-3; 87596LJ, USA). However, in mice, cyclophosphamide (Fosfaseron, Filaxis, Lot: $06,307 \mathrm{D}$, Brazil), which is a chemotherapy drug, was used the dose of $100 \mathrm{mg} / \mathrm{kg}$ body weight ( $\mathrm{bw}$ ), administered intraperitoneally ( $\mathrm{ip}$ ), and diluted in $0.9 \%$ saline solution.

\section{Experimental design}

\section{A. cepa test}

As reported in the literature, the A. cepa test consists of the analysis of the meristematic cells of $A$. cepa in order to identify chromosomal alterations (Fernandes et al., 2007; Leme and Marin-Morales, 2009). The biological assay was performed with seeds (Top Seed, Brazil) of $A$. серa $(2 \mathrm{n}=16$ chromosomes). The seeds were germinated and grown in Petri dishes lined with filter paper soaked in distilled water at room temperature (Fernandes et al., 2007). The treatments to determine mutagenicity were negative control, positive control (MMS), and MEST.

To evaluate the antimutagenicity and to elucidate the mode of antimutagenic action, various treatment protocols were conducted using the DNA-damaging agent (MMS), which induces lesions such as breaks, bridges, and chromosome losses in the genetic material; these lesions are also expressed in the form of micronuclei (Rank and Nielsen, 1997; Oliveira et al., 2006). Therefore, the following protocols were performed: pre-treatment to indicate preferentially desmutagenic action; simple simultaneous treatment to assess desmutagenic and biomutagenic activity; simultaneous treatment with pre-incubation for desmutagenic activity; and post-treatment to indicate biomutagenic action (Antunes and Araújo, 2000; Oliveira et al., 2006, 2007; Malini et al., 2010).

The treatments and protocols were conducted according Oliveira et al. $(2006,2007)$, with modifications (Figure 1) as described. In the negative control, the seeds were grown for $24 \mathrm{~h}$ in distilled water and $96 \mathrm{~h}$ in $3 \mathrm{~mL} \mathrm{1 \%}$ methanol. In the positive control (MMS), the seeds were grown for $72 \mathrm{~h}$ in distilled water and $48 \mathrm{~h}$ in MMS aqueous solution. In the MEST condition, the seeds were grown for $24 \mathrm{~h}$ in distilled water and $96 \mathrm{~h}$ in MEST solutions at three different concentrations in independent experiments. In the pre-treatment condition, the seeds were grown in distilled water for $24 \mathrm{~h}$ and in MEST solution for $48 \mathrm{~h}$; then, the seeds were rinsed in distilled water and germinated for an additional $48 \mathrm{~h}$ in aqueous MMS. In the simple simultaneous treatment, the seeds were grown in distilled water for $72 \mathrm{~h}$ and then in MEST and MMS solution; this protocol establishes the germination of seeds in the simultane- 
ous presence of the two compounds for a period of $48 \mathrm{~h}$. In the simultaneous treatment with pre-incubation, the seeds were grown in distilled water for $72 \mathrm{~h}$; after this period, the seeds were kept for another $48 \mathrm{~h}$ in the presence of MMS and MEST, which were previously incubated for $1 \mathrm{~h}$ at $37^{\circ} \mathrm{C}$ before being administered to the seeds, to evaluate desmutagenicity. In the post-treatment, the seeds were grown in distilled water for $24 \mathrm{~h}$; after this period, the seeds were kept for another $48 \mathrm{~h}$ in aqueous MMS, rinsed in distilled water, and germinated for an additional $48 \mathrm{~h}$ in MEST solution. All treatments and protocols were performed in triplicate for the three different concentrations of MEST that were tested.

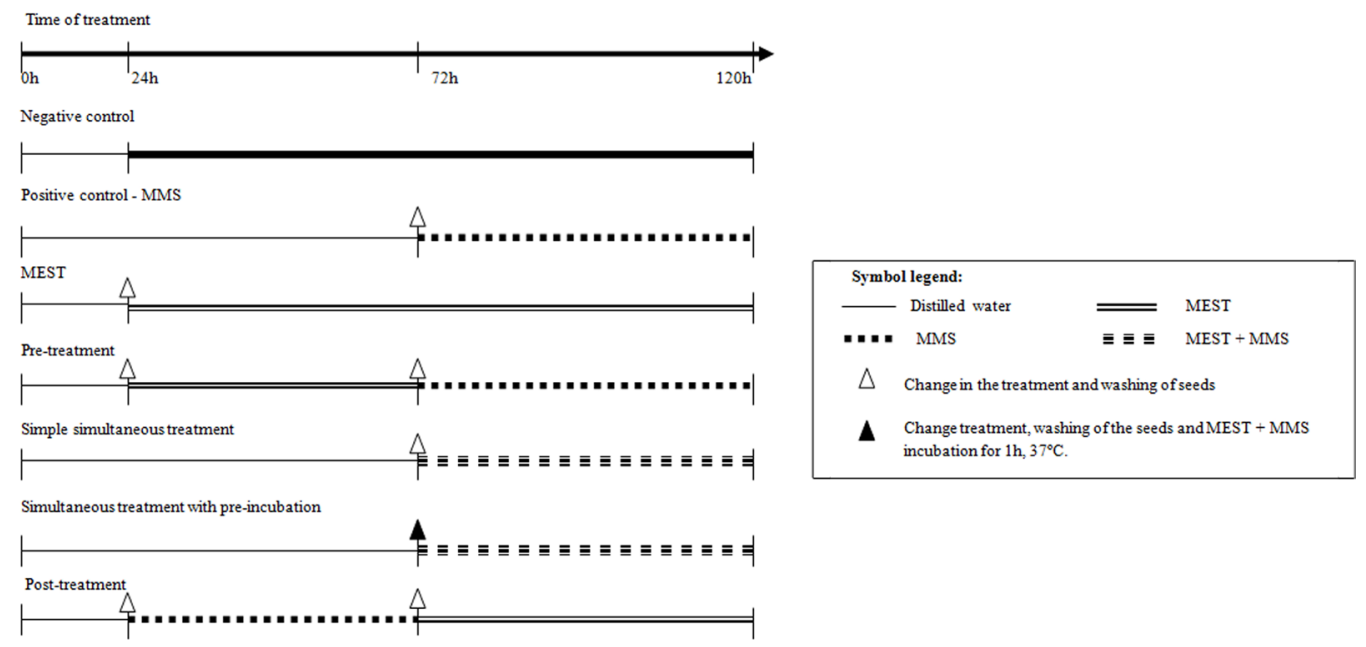

Figure 1. Allium cepa experimental design.

After $120 \mathrm{~h}$ of cultivation and germination of $A$. cepa seeds, the roots were collected and prepared according to the protocol of Fernandes et al. (2007). To obtain permanent slides, the slides were fully immersed in liquid nitrogen to remove the coverslip and dried at room temperature. A new cover slip was added over the biological material with the aid of synthetic resin $\left(\right.$ Permount $\left.{ }^{\mathbb{R}}\right)$. After drying the material for $24 \mathrm{~h}$, microscopic analyses were performed on a Physis EXP 100 microscope. In general, 15,000 cells were analyzed per treatment/protocol by light microscopy with a 40X objective. The mitotic index (MI) and the percentage of damage reduction (DR\%) were calculated. In order to obtain the MI, the number of dividing cells (prophase, metaphase, anaphase, and telophase) was divided by the total number of cells analyzed.

\section{Animal experiment}

Thirty male Swiss mice (Mus musculus) at reproductive age with an average weight of 30 g, were obtained from the animal house of the Centro de Ciências Biológicas e da Saúde, Universidade Federal de Mato Grosso do Sul (CCBS/UFMS). The mice were divided into six groups $(\mathrm{N}=5)$. They were housed in a standard animal facility under controlled temperature $\left(22^{\circ} \mathrm{C}\right)$ and photoperiod $(12 \mathrm{~h}$ light, $12 \mathrm{~h}$ dark) with access to water and rodent food ad libitum. All procedures and protocols followed approved guidelines for the ethical treatment of 
animals according to the Ethics Committee in Animal Experimentation from the Universidade Federal de Mato Grosso do Sul (Protocol No. 398/2012).

The experimental tests were performed using the protocols of pre-treatment, simultaneous treatment, and post-treatment (Figure 2) in relation to cyclophosphamide, which is an alkylating compound with an indirect action that is capable of establishing covalent bonds between base pairs of the DNA molecule and generating genotoxic damage and chromosomal instability (Ramadan et al., 2012).
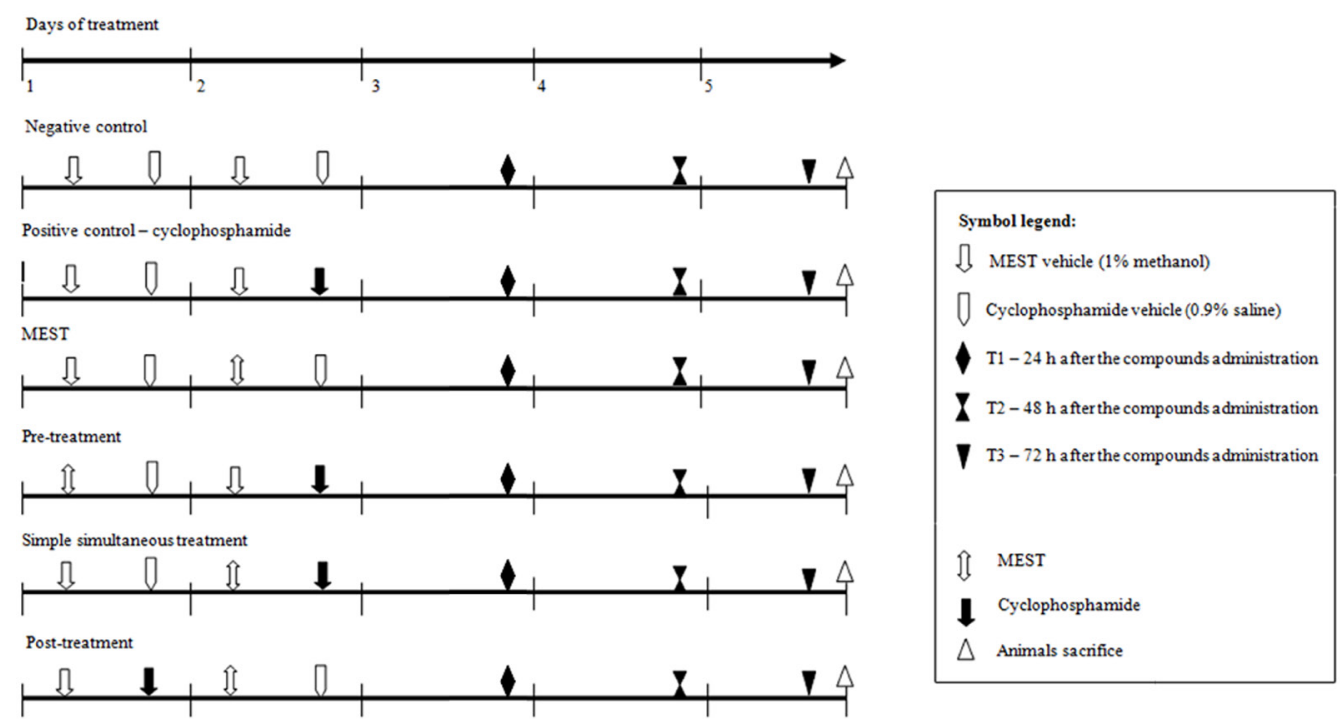

Figure 2. Mice experimental design.

The experimental groups were subjected to peripheral blood collection through the puncture of the tail vein for the genotoxicity and antigenotoxicity (comet assay) and for mutagenicity and antimutagenicity (micronucleus assay) evaluation. The blood samples were collected 24, 48, and $72 \mathrm{~h}$ after the last administration of test compounds and were designated $\mathrm{T} 1$, $\mathrm{T} 2$, and T3, respectively. T1 corresponds to the collection for comet and micronucleus assay, and $\mathrm{T} 2$ and $\mathrm{T} 3$ correspond to peripheral blood collected by the micronucleus assay.

The treatments and protocols were conducted according to Oliveira et al. (2009) with modifications, as described. In the negative control, the MEST vehicle (1\% methanol, 0.1 $\mathrm{mL} / 10 \mathrm{~g} b w$ via gavage) and cyclophosphamide vehicle (0.9\% saline, $0.1 \mathrm{~mL} / 10 \mathrm{~g}$ bw ip) were administered the first and second days of treatment. In the positive control, the mice were exposed to the same treatment as the negative control group; however, on the second day, the mice received cyclophosphamide at a dose of $100 \mathrm{mg} / \mathrm{kg}$ instead of saline. In the MEST condition, the mice were subjected to the same treatment as the negative control group, but the mice received $16.8 \mathrm{mg} / \mathrm{kg}$ MEST instead of $1 \%$ methanol on the second day. In the pretreatment group, the mice were subjected to the same treatment as the negative control group, but the mice received MEST at a concentration of $16.8 \mathrm{mg} / \mathrm{kg}$ instead of $1 \%$ methanol on the first day and $100 \mathrm{mg} / \mathrm{kg}$ cyclophosphamide instead of saline on the second day. In the simultaneous 
group, the mice were subjected to the same treatment as the negative control group; however, the mice received MEST at a concentration of $16.8 \mathrm{mg} / \mathrm{kg}$ instead of $1 \%$ methanol and 100 $\mathrm{mg} / \mathrm{kg}$ cyclophosphamide instead of saline on the second day. In the post-treatment, the mice were subjected to the same treatment as the negative control group, but the mice received 100 $\mathrm{mg} / \mathrm{kg}$ cyclophosphamide instead of saline on the first day and MEST at a concentration of $16.8 \mathrm{mg} / \mathrm{kg}$ instead of $1 \%$ methanol on the second day.

Seventy-two hours after the last administration of MEST and/or cyclophosphamide and after the blood sample collection at 24,48 , and $72 \mathrm{~h}$, the mice were weighed and euthanized by cervical dislocation. Then, the spleen, kidneys, lungs, heart, and liver were collected and weighed.

\section{Comet assay in peripheral blood}

The comet assay in peripheral blood was used to evaluate genotoxicity and antigenotoxicity. It was performed according to Singh et al. (1988) with the modifications that were reported by Oliveira et al. (2009). The cells were evaluated with a fluorescence microscope (Nikon) using a 40X objective, an excitation filter of $420-490 \mathrm{~nm}$, and barrier filter of $520 \mathrm{~nm}$. A total of 100 cells per treatment were analyzed, and the comets were classified as described by Kobayashi et al. (1995).

\section{Micronucleus assay in peripheral blood}

In order to evaluate the mutagenicity and antimutagenicity in peripheral blood, the micronucleus assay was performed. The method that was described by Hayashi et al. (1990) and modified by Oliveira et al. (2009) was used in this experiment. A total of 2000 cells/mice were analyzed using an epifluorescence microscope (Bioval $\left.{ }^{\mathbb{B}} \mathrm{L}-2000 \mathrm{~A}\right)$ with a $40 \mathrm{X}$ objective using an excitation filter $(490 \mathrm{~nm})$ and a barrier filter $(420-520 \mathrm{~nm})$.

\section{Calculating the DR\%}

The DR\% by MEST of damage caused by the mutagenic and/or genotoxic agent was performed as suggested by Manoharan and Banerjee (1985) and Waters et al. (1990), where

$$
\mathrm{DR} \%=\left[\frac{\text { Mean of positive control }- \text { Mean of associated group }}{\text { Mean of positive control }- \text { Mean of negative control }}\right] \times 100
$$

\section{Statistical analyses}

Values are reported as means \pm SE, and data were analyzed using one-way analysis of variance followed by the Tukey post-test using GraphPad Prism (version 3.02; Graph-Pad Software Inc., San Diego, CA, USA). The significance level was set at $\mathrm{P}<0.05$.

\section{RESULTS}

The MEST had a yield of $14 \%$. The MEST showed $544.14 \mathrm{mg} / \mathrm{g}$ of total phenols by 
Folin-Ciocalteu and expressed as milligrams gallic acid equivalents per gram extract. The flavonoid content was $460.20 \mathrm{mg}$ quercetin per g extract.

\section{A. cepa test}

Table 1 shows the results of mutagenicity and antimutagenicity obtained by the $A$. cepa test. The results indicate that MEST has no mutagenic activity; however, it demonstrates efficient antimutagenic action in the three concentrations that were tested. The most frequent chromosomal alterations caused by MMS that were observed in this study were micronuclei, segregation chromosomal delay, and chromosome bridges in anaphase and telophase.

\begin{tabular}{|c|c|c|c|c|c|c|c|c|c|c|}
\hline \multirow[t]{2}{*}{ Treatment } & \multirow[t]{2}{*}{ MI } & \multicolumn{6}{|c|}{ Chromosomal alterations } & \multicolumn{2}{|c|}{ Frequency } & \multirow[t]{2}{*}{$\mathrm{DR} \%$} \\
\hline & & $\mathrm{MN}$ & Bridge & Break & Loss & NB & Delay & Total & Means $\pm \mathrm{SE}$ & \\
\hline \multicolumn{11}{|l|}{ Mutagenicity } \\
\hline Negative control & $18.56^{\mathrm{a}-\mathrm{b}}$ & 8 & 23 & 4 & 7 & 0 & 26 & 68 & $22.67 \pm 2.19^{\mathrm{a}}$ & - \\
\hline Positive control - MMS & $11.77^{\mathrm{a}}$ & 330 & 51 & 20 & 21 & 7 & 57 & 486 & $162.00 \pm 13.58^{\mathrm{e}}$ & - \\
\hline \multicolumn{11}{|l|}{ Schinus terebinthifolius } \\
\hline MEST $16.8 \mathrm{mg} / \mathrm{L}$ & $29.03^{\mathrm{b}-\mathrm{f}}$ & 20 & 17 & 2 & 6 & 2 & 56 & 103 & $34.33 \pm 2.40^{\mathrm{a}, \mathrm{b}}$ & - \\
\hline MEST $33.6 \mathrm{mg} / \mathrm{L}$ & $33.58^{\mathrm{c}-\mathrm{f}}$ & 33 & 40 & 8 & 24 & 1 & 42 & 148 & $49.33 \pm 2.03^{\mathrm{a}, \mathrm{b}, \mathrm{c}}$ & - \\
\hline MEST $50.4 \mathrm{mg} / \mathrm{L}$ & $21.11^{\mathrm{b}-\mathrm{f}}$ & 28 & 38 & 12 & 25 & 1 & 45 & 149 & $49.67 \pm 1.86^{\mathrm{a}, \mathrm{b}, \mathrm{c}}$ & - \\
\hline \multicolumn{11}{|l|}{ Antimutagenicity } \\
\hline \multicolumn{11}{|l|}{ Pre-treatment } \\
\hline MEST $16.8 \mathrm{mg} / \mathrm{L}$ & $21.96^{\mathrm{a}-\mathrm{e}}$ & 93 & 17 & 2 & 6 & 4 & 22 & 144 & $48.00 \pm 15.31^{\mathrm{a}-\mathrm{c}}$ & 81.82 \\
\hline MEST $33.6 \mathrm{mg} / \mathrm{L}$ & $19.97^{\mathrm{a}-\mathrm{c}}$ & 122 & 22 & 3 & 13 & 6 & 31 & 197 & $65.67 \pm 6.01^{\mathrm{b}, \mathrm{c}}$ & 69.15 \\
\hline MEST $50.4 \mathrm{mg} / \mathrm{L}$ & $20.67^{\mathrm{a}-\mathrm{c}}$ & 174 & 51 & 9 & 13 & 2 & 64 & 313 & $104.33 \pm 9.49^{\mathrm{d}}$ & 41.39 \\
\hline \multicolumn{11}{|c|}{ Simple simultaneous treatment } \\
\hline MEST $16.8 \mathrm{mg} / \mathrm{L}$ & $31.94^{\mathrm{d}-\mathrm{f}}$ & 59 & 22 & 3 & 6 & 1 & 52 & 143 & $47.67 \pm 6.49^{\mathrm{a}, \mathrm{b}, \mathrm{c}}$ & 82.06 \\
\hline MEST $33.6 \mathrm{mg} / \mathrm{L}$ & $27.77^{\mathrm{b}-\mathrm{f}}$ & 40 & 27 & 2 & 10 & 2 & 56 & 137 & $45.67 \pm 2.73^{\mathrm{a}, \mathrm{b}, \mathrm{c}}$ & 83.49 \\
\hline MEST $50.4 \mathrm{mg} / \mathrm{L}$ & $29.02^{\mathrm{b-f}}$ & 108 & 23 & 13 & 15 & 6 & 31 & 220 & $73.33 \pm 10.73^{b, c, d}$ & 64.64 \\
\hline \multicolumn{11}{|l|}{$\begin{array}{l}\text { Simultaneous treatment } \\
\text { with pre-incubation }\end{array}$} \\
\hline MEST $16.8 \mathrm{mg} / \mathrm{L}$ & $32.13^{\mathrm{d}-\mathrm{f}}$ & 26 & 30 & 1 & 7 & 1 & 65 & 130 & $43.33 \pm 2.60^{\mathrm{a}, \mathrm{b}}$ & 85.17 \\
\hline MEST $33.6 \mathrm{mg} / \mathrm{L}$ & $30.92^{\mathrm{c}-\mathrm{f}}$ & 47 & 25 & 3 & 5 & 2 & 64 & 146 & $48.67 \pm 5.90^{a-c}$ & 81.34 \\
\hline MEST $50.4 \mathrm{mg} / \mathrm{L}$ & $32.48^{\mathrm{c}-\mathrm{f}}$ & 156 & 30 & 12 & 14 & 8 & 30 & 250 & $83.33 \pm 9.24^{\mathrm{c}, \mathrm{d}}$ & 56.46 \\
\hline \multicolumn{11}{|l|}{ Post-treatment } \\
\hline MEST $16.8 \mathrm{mg} / \mathrm{L}$ & $32.04^{\mathrm{d}-\mathrm{f}}$ & 19 & 26 & 2 & 7 & 1 & 66 & 121 & $40.33 \pm 3.53^{\mathrm{a}, \mathrm{b}}$ & 87.33 \\
\hline MEST $33.6 \mathrm{mg} / \mathrm{L}$ & $34.52^{\mathrm{f}}$ & 22 & 38 & 4 & 17 & 0 & 52 & 133 & $44.33 \pm 5.81^{\mathrm{a}, \mathrm{b}}$ & 84.45 \\
\hline MEST $50.4 \mathrm{mg} / \mathrm{L}$ & $22.92^{\mathrm{a}-\mathrm{e}}$ & 80 & 31 & 5 & 23 & 9 & 53 & 201 & $67.00 \pm 2.08^{\mathrm{b}, \mathrm{c}}$ & 68.18 \\
\hline
\end{tabular}

MMS = methyl methane sulfonate; MEST $=$ methanolic extract of Schinus terebinthifolius leaves; $\mathrm{MI}=$ mitotic index; $\mathrm{MN}=$ micronucleus; $\mathrm{NB}=$ nuclear bud; $\mathrm{SE}=$ standard error. Different letters indicate significant differences (statistical test: snalysis of variance - ANOVA/Tukey; $\mathrm{P}<0.05$ ).

Regarding the MI, the values for negative and positive controls were 18.56 and 11.77 , respectively. These results indicate that MMS developed its mutagenic activity without interrupting the cell cycle, and this characteristic is required to validate the proposed test for this research. For cells treated with MEST at concentrations of 16.8 and $50.4 \mathrm{mg} / \mathrm{mL}$, the MI values were similar to that of the negative control, and the MI was higher at a MEST concentration of $33.6 \mathrm{mg} / \mathrm{mL}$ than in the negative control. The antimutagenicity analyses showed that the MI in all protocols and doses evaluated were higher than the positive control. This result shows that the tested doses could be used in antimutagenicity tests. 


\section{Animal experiment}

Table 2 shows the mice $b w$ and the absolute and relative weights of the heart, lung, liver, kidney, and spleen. The results demonstrate that biometric parameters were similar to the negative control, except that the spleen relative weight decreased in all cyclophosphamide-treated groups.

\begin{tabular}{|c|c|c|c|c|c|c|}
\hline Experimental group & Negative control & Positive control & MEST & Pre-treatment & Simultaneous & Post-treatment \\
\hline \multicolumn{7}{|l|}{ Animal's weight } \\
\hline Initial (g) & $26.25 \pm 0.37^{\mathrm{a}}$ & $25.05 \pm 0.37^{\mathrm{a}}$ & $26.99 \pm 0.56^{\mathrm{a}}$ & $25.09 \pm 0.80^{\mathrm{a}}$ & $26.05 \pm 0.95^{\mathrm{a}}$ & $28.15 \pm 2.02^{\mathrm{a}}$ \\
\hline Final (g) & $26.15 \pm 0.58^{\mathrm{a}}$ & $24.38 \pm 1.21^{\mathrm{a}}$ & $27.10 \pm 0.56^{\mathrm{a}}$ & $24.63 \pm 0.96^{\mathrm{a}}$ & $24.92 \pm 0.70^{\mathrm{a}}$ & $28.44 \pm 2.22^{\mathrm{a}}$ \\
\hline Liquid weight gain ( $g$ ) & $-0.10 \pm 0.40^{a}$ & $-0.66 \pm 0.32^{\mathrm{a}}$ & $0.10 \pm 0.22^{\mathrm{a}}$ & $-0.46 \pm 0.24^{a}$ & $-1.13 \pm 0.38^{\mathrm{a}}$ & $0.29 \pm 0.40^{\mathrm{a}}$ \\
\hline \multicolumn{7}{|c|}{$\begin{array}{l}\text { Absolute organ } \\
\text { weight }(\mathrm{g})\end{array}$} \\
\hline Heart & $0.1564 \pm 0.0086^{a, b}$ & $0.1497 \pm 0.0106^{\mathrm{a}, \mathrm{b}}$ & $0.1561 \pm 0.0094^{\mathrm{a}, \mathrm{b}}$ & $0.1439 \pm 0.0110^{\mathrm{a}}$ & $0.1306 \pm 0.0049^{\mathrm{a}}$ & $0.1936 \pm 0.0163^{b}$ \\
\hline Lung & $0.1980 \pm 0.0076^{\mathrm{a}, \mathrm{b}}$ & $0.1780 \pm 0.0103^{\mathrm{a}}$ & $0.2031 \pm 0.0138^{\mathrm{a}, \mathrm{b}}$ & $0.1811 \pm 0.0076^{\mathrm{a}}$ & $0.1876 \pm 0.0095^{\mathrm{a}, \mathrm{b}}$ & $0.2297 \pm 0.0133^{\mathrm{b}}$ \\
\hline Liver & $1.5884 \pm 0.0188^{\mathrm{a}}$ & $1.4993 \pm 0.0557^{\mathrm{a}}$ & $1.6337 \pm 0.0676^{\mathrm{a}}$ & $1.4294 \pm 0.0586^{\mathrm{a}}$ & $1.4439 \pm 0.0452^{\mathrm{a}}$ & $1.5636 \pm 0.0797^{\mathrm{a}}$ \\
\hline Kidney & $0.3695 \pm 0.0115^{\mathrm{a}}$ & $0.3623 \pm 0.0190^{\mathrm{a}}$ & $0.3538 \pm 0.0109^{\mathrm{a}}$ & $0.3521 \pm 0.0077^{\mathrm{a}}$ & $0.3672 \pm 0.0107^{\mathrm{a}}$ & $0.4297 \pm 0.0355^{\mathrm{a}}$ \\
\hline Spleen & $0.1302 \pm 0.0060^{\mathrm{a}, \mathrm{b}}$ & $0.0833 \pm 0.0033^{b, c}$ & $0.1277 \pm 0.0105^{\mathrm{a}-\mathrm{c}}$ & $0.0768 \pm 0.0054^{\mathrm{a}}$ & $0.0765 \pm 0.0029^{\mathrm{a}}$ & $0.1369 \pm 0.0254^{c}$ \\
\hline \multicolumn{7}{|l|}{$\begin{array}{l}\text { Relative organ } \\
\text { weight }(\mathrm{g})\end{array}$} \\
\hline Heart & $0.0060 \pm 0.0003^{\mathrm{a}}$ & $0.0062 \pm 0.0004^{\mathrm{a}}$ & $0.0058 \pm 0.0003^{\mathrm{a}}$ & $0.0058 \pm 00004^{\mathrm{a}}$ & $0.0053 \pm 0.0003^{\mathrm{a}}$ & $0.0068 \pm 0.0002^{\mathrm{a}}$ \\
\hline Lung & $0.0076 \pm 0.0002^{\mathrm{a}}$ & $0.0073 \pm 0.0004^{\mathrm{a}}$ & $0.0075 \pm 0.0006^{\mathrm{a}}$ & $0.0074 \pm 0.0002^{\mathrm{a}}$ & $0.0075 \pm 0.0003^{\mathrm{a}}$ & $0.0083 \pm 0.0007^{\mathrm{a}}$ \\
\hline Liver & $0.0609 \pm 0.0016^{\mathrm{a}}$ & $0.0621 \pm 0.0038^{\mathrm{a}}$ & $0.0604 \pm 0.0030^{\mathrm{a}}$ & $0.0582 \pm 0.0020^{\mathrm{a}}$ & $0.0579 \pm 0.0009^{\mathrm{a}}$ & $0.0562 \pm 0.0047^{\mathrm{a}}$ \\
\hline Kidney & $0.0141 \pm 0.0003^{\mathrm{a}, \mathrm{b}}$ & $0.0149 \pm 0.0007^{\mathrm{b}, \mathrm{c}}$ & $0.0131 \pm 0.0005^{\mathrm{a}}$ & $0.0143 \pm 0.0004^{\mathrm{a}, \mathrm{b}}$ & $0.0147 \pm 0.0002^{\mathrm{a}, \mathrm{b}}$ & $0.0151 \pm 0.0003^{b, c}$ \\
\hline Spleen & $0.0050 \pm 0.0002^{\mathrm{a}}$ & $0.0035 \pm 0.0002^{\mathrm{b}}$ & $0.0047 \pm 0.0004^{\mathrm{a}}$ & $0.0031 \pm 0.0002^{\mathrm{b}}$ & $0.0031 \pm 0.0001^{\mathrm{b}}$ & $0.0042 \pm 0.0004^{\mathrm{a}, \mathrm{b}}$ \\
\hline
\end{tabular}

\section{Comet assay in peripheral blood}

Table 3 presents the average frequency of damaged cells, the distribution of cells among the damage classes, scores, and DR\% in DNA tests related to genotoxicity and antigenotoxicity in the different protocols that were evaluated. The results of the MEST group were similar to those of the negative control, demonstrating the absence of MEST genotoxic activity under the conditions that were studied. The antigenotoxicity evaluation showed damage reduction in all protocols analyzed; however, the post-treatment group had the highest DR\%, with an average frequency of damaged cells $(17.00 \pm 9.66)$ that was similar to that of the negative control group $(18.40 \pm 3.42)$.

\section{Micronucleus assay in peripheral blood}

Table 4 presents the total frequency, average frequency, and DR\% for the micronucleus test in peripheral blood. The results indicate that MEST has no mutagenic activity at the dose that was tested. Regarding the antimutagenicity evaluation, MEST was effective in reducing the damage caused by cyclophosphamide, especially in the simultaneous and posttreatment groups, which expressed the highest DR\% ( 82.53 and $95.78 \%$, respectively). It is important to note that the DR\% values increased over time (T1, T2, and T3) for all protocols analyzed, confirming the MEST efficiency as an antimutagenic agent. 
Table 3. Mean frequency of lesioned cells \pm SE, distribution among classes of damage and score related to genotoxicity and antigenotoxicity tests at the comet assay in peripheral blood of Swiss male mice.

\begin{tabular}{|c|c|c|c|c|c|c|c|}
\hline \multirow[t]{2}{*}{ Experimental group } & \multirow[t]{2}{*}{ Lesioned cells } & \multicolumn{4}{|c|}{ Classes of DNA damage } & \multirow[t]{2}{*}{ Score } & \multirow[t]{2}{*}{$\mathrm{DR} \%$} \\
\hline & & 0 & 1 & 2 & 3 & & \\
\hline \multicolumn{8}{|l|}{ Genotoxicity } \\
\hline Negative control & $18.40 \pm 3.42^{\mathrm{a}}$ & $81.60 \pm 3.42^{\mathrm{b}}$ & $17.40 \pm 3.14^{\mathrm{a}}$ & $1.00 \pm 0.45^{\mathrm{a}, \mathrm{b}}$ & $0.00 \pm 0.00^{\mathrm{a}}$ & $19.40 \pm 3.72^{\mathrm{a}}$ & - \\
\hline Positive control & $70.60 \pm 5.27^{\mathrm{b}}$ & $29.40 \pm 5.27^{\mathrm{a}}$ & $63.80 \pm 4.45^{\mathrm{c}}$ & $5.60 \pm 1.44^{d}$ & $1.20 \pm 0.37^{\mathrm{b}}$ & $76.80 \pm 6.67^{b}$ & - \\
\hline MEST & $28.40 \pm 9.53^{\mathrm{a}, \mathrm{b}}$ & $71.60 \pm 9.53^{b}$ & $28.00 \pm 9.41^{\mathrm{a}, \mathrm{b}}$ & $0.40 \pm 0.25^{\mathrm{a}}$ & $0.00 \pm 0.00^{\mathrm{a}}$ & $28.00 \pm 9.65^{\mathrm{a}, \mathrm{b}}$ & - \\
\hline \multicolumn{8}{|l|}{ Antigenotoxicity } \\
\hline Pre-treatment & $45.50 \pm 5.50^{\mathrm{a}, \mathrm{b}}$ & $54.50 \pm 5.50^{\mathrm{a}, \mathrm{b}}$ & $40.50 \pm 4.65^{\mathrm{a}-\mathrm{c}}$ & $4.50 \pm 0.50^{\mathrm{b}-\mathrm{d}}$ & $0.50 \pm 0.50^{\mathrm{a}, \mathrm{b}}$ & $51.00 \pm 6.86^{\mathrm{a}, \mathrm{b}}$ & 48.01 \\
\hline Simultaneous & $58.80 \pm 11.07^{\mathrm{b}}$ & $41.20 \pm 11.07^{\mathrm{a}}$ & $56.60 \pm 10.09^{\mathrm{b}, \mathrm{c}}$ & $2.20 \pm 1.16^{\mathrm{a}-\mathrm{d}}$ & $0.00 \pm 0.00^{\mathrm{a}}$ & $61.00 \pm 12.07^{\mathrm{b}}$ & 22.61 \\
\hline Post-treatment & $17.00 \pm 9.66^{\mathrm{a}}$ & $83.00 \pm 9.66^{b, c}$ & $17.00 \pm 9.66^{\mathrm{a}}$ & $0.00 \pm 0.00^{\mathrm{a}}$ & $0.00 \pm 0.00^{\mathrm{a}}$ & $17.00 \pm 9.66^{\mathrm{a}}$ & 102.69 \\
\hline
\end{tabular}

$\mathrm{DR} \%=$ damage reduction percentage; MEST $=$ methanolic extract of Schinus terebinthifolius leaves. $\mathrm{SE}=$ standard error. Different letters mean significant differences (statistical test: analysis of variance: ANOVA/Tukey; $\mathrm{P}<0.05$ ).

Table 4. Total frequency, frequency means \pm SE, percentage of damage reduction (DR\%) related to tests for mutagenicity and antimutagenicity in micronucleus (MN) test in peripheral blood of Swiss male mice.

\begin{tabular}{|c|c|c|c|c|c|c|c|c|c|}
\hline \multirow[t]{2}{*}{ Experimental group } & \multicolumn{3}{|c|}{ MN frequency } & \multicolumn{3}{|c|}{ Means $\pm \mathrm{SE}$} & \multicolumn{3}{|c|}{$\mathrm{DR} \%$} \\
\hline & $\mathrm{T} 1$ & $\mathrm{~T} 2$ & $\mathrm{~T} 3$ & $\mathrm{~T} 1$ & $\mathrm{~T} 2$ & $\mathrm{~T} 3$ & $\mathrm{~T} 1$ & $\mathrm{~T} 2$ & $\mathrm{~T} 3$ \\
\hline \multicolumn{10}{|l|}{ Mutagenicity } \\
\hline Negative control & 99 & 93 & 84 & $10.40 \pm 0.93^{\mathrm{a}}$ & $9.80 \pm 1.32^{\mathrm{a}}$ & $8.60 \pm 1.03^{\mathrm{a}}$ & - & - & - \\
\hline Positive control & 473 & 432 & 387 & $48.80 \pm 3.88^{c}$ & $41.60 \pm 3.89^{c}$ & $41.80 \pm 4.77^{\mathrm{c}}$ & - & - & - \\
\hline MEST & 106 & 124 & 118 & $8.80 \pm 0.58^{\mathrm{a}}$ & $11.00 \pm 1.76^{\mathrm{a}, \mathrm{b}}$ & $10.80 \pm 1.28^{\mathrm{a}}$ & - & - & - \\
\hline \multicolumn{10}{|l|}{ Antimutagenicity } \\
\hline Pre-treatment & 427 & 292 & 219 & $43.80 \pm 1.66^{\mathrm{c}}$ & $32.00 \pm 1.87^{c}$ & $24.40 \pm 2.50^{\mathrm{b}}$ & 13.02 & 30.19 & 52.41 \\
\hline Simultaneous & 274 & 205 & 151 & $26.20 \pm 3.15^{b}$ & $20.40 \pm 2.25^{\mathrm{b}}$ & $14.40 \pm 1.69^{\mathrm{a}, \mathrm{b}}$ & 58.86 & 66.67 & 82.53 \\
\hline Post-treatment & 225 & 132 & 98 & $19.60 \pm 3.64^{\mathrm{a}, \mathrm{b}}$ & $12.20 \pm 1.07^{\mathrm{a}, \mathrm{b}}$ & $10.00 \pm 1.95^{\mathrm{a}}$ & 76.04 & 92.46 & 95.78 \\
\hline
\end{tabular}

$\mathrm{SE}=$ standard error; T1, T2, T3 = collection time; Different letters mean significant differences (statistical test: analysis of variance $=$ ANOVA/Tukey; $\mathrm{P}<0.05$ ).

\section{DISCUSSION}

A major concern regarding the use of medicinal plants has been whether they interact with genetic material (de Carvalho et al., 2003). S. terebinthifolius is widely used in folk medicine to treat diseases such as ulcers, respiratory problems, wounds, rheumatism, gout, diarrhea, and tumors (Santana et al., 2012). However, its chemopreventive activity has not been reported. The aim of this study was to evaluate the effects of the MEST in the prevention and/ or repair of genotoxic and mutagenic lesions, describe the mode of action of chemopreventive MEST in A. cepa and Swiss mice, and compare the two biological models.

The $A$. cepa test results showed that the lowest MEST concentration that was tested had the most effective chemopreventive activity with a dose-response correlation that was inversely proportional. This suggests that differences in the final balance of the concentrations of phytochemicals, pro-oxidants, and antioxidants in the different concentrations tested contributed to the indication of the lowest dose as the most efficient dose to prevent mutagenic damage. This hypothesis is strengthened by de Carvalho et al. (2003) and Varela-Barca et al. (2007), who demonstrated that flavonoids such as quercetin and amentoflavone acted as prooxidant flavonoids at high concentrations, showing a genotoxic effect in the decoction of the stem bark of S. terebinthifolius in bacteria tests. Thus, in our study, higher concentrations of 
phenolic compounds such as quercetin and biflavonoids (Varela-Barca et al., 2007) that are present in higher MEST concentrations could have reduced the antioxidant action, conferring a decreased antimutagenic activity.

Regarding the A. серa MI, an increased tendency could be observed in the MEST treatment alone, as well as in the groups associated with MMS. According to Fiskesjö (1993), an MI inhibition of 36\% in A. cepa apical meristems against chemicals is considered normal, and values greater than $50 \%$ could be considered cytotoxic. However, it is important to note that the extract tested, instead of causing cytotoxicity in isolated meristematic cells or associated with the MMS, was effective in improving the MI, which shows an ability to modulate events to reduce the alkylating agent toxicity through direct inhibition, such as adsorption and/ or contributing to mechanisms of replication and DNA repair (Oliveira et al., 2006).

The DR\% results that were observed in A. cepa and mice showed the MEST antimutagenic and antigenotoxic activities for the two models, as well as its lack of toxicity, genotoxicity, and mutagenicity. Ramos Ruiz et al. (1996) also noted the absence of toxic and genotoxic effects for the hydroalcoholic extract of S. terebinthifolius leaves in an Aspergillus nidulans experimental model. Regarding the results of the different protocols that were examined, the MEST mode of action was chemopreventive, desmutagenic, and bioantimutagenic in A. cepa, and preferably bioantimutagenic in mice.

In general, there are two classes of protective substances against DNA damage: those with a desmutagenic mechanism and those with a bioantimutagenic mechanism (Kada et al., 1982). Desmutagenic substances are able to block the action of DNA damage-inducing agents, mainly by their adsorption, acting preferentially in extracellular medium. On the other hand, bioantimutagenic agents are those capable of exerting their effect by preventing DNA lesions or promoting DNA repair, thus acting inside the cell (Kada and Shimoi, 1987). The bioantimutagenic substances act as modulators of DNA replication and repair, stimulate error-free repair of DNA damage, or inhibit repair systems that are subject to error (De Flora 1998; Oliveira et al., 2006).

The desmutagenic mode of action was assessed by the pre-treatment protocol (Antunes and Araújo, 2000), and the DR\% was lower in mice than in A. cepa. This difference could be because of variations in bioavailability, metabolism, and clearance of substances in the different models analyzed. In plants, the oxidase enzyme system is stimulated at lower concentrations than the mammalian cytochrome P450 system, and there is a limitation in its specificity to several substrates (Rank and Nielsen, 1997). Taking this into account, $A$. cepa metabolism would require more time than mouse metabolism. Therefore, in the $A$. cepa pretreatment group, the MEST active compounds would be in the cytoplasm (Oliveira et al., 2007 ) at the time of MMS administration and would act directly on this compound, inactivating it by desmutagenesis.

In the $A$. cepa test, the desmutagenic mode of action was confirmed by the simultaneous treatment with the pre-incubation protocol, demonstrating the MEST efficiency in adsorbing and/or chemically inactivating the MMS. This protocol was not developed in mice because it was impossible to pre-incubate substances before administering them to the mice because of the different routes of administration of the MEST (oral) and cyclophosphamide (intraperitoneal).

To validate the MEST bioantimutagenic mode of action, we used the post-treatment protocol, which showed the highest rates of chemoprevention in both experimental models ( $A$. cepa and mice). However, in the mice model, the antimutagenic action was superior to that observed in A. cepa, and the antigenotoxic action presented a DR\% that was greater than $100 \%$. 
This suggests that MEST was effective in reducing even the basal spontaneous damage that was observed in the negative control, where there was no prior exposure to genotoxic agents (Martins de Oliveira et al., 2002).

As confirmation of the results that were obtained in protocols that were previously discussed, we used the simple simultaneous treatment, which allows the evaluation of the antimutagenic activity by both modes of action: desmutagenic and bioantimutagenic (Antunes and Araújo, 2000; Oliveira et al., 2006; Malini et al., 2010). The results of simultaneous association suggest the MEST desmutagenesis and bioantimutagenesis efficiency for MMS in A. серa and important bioantimutagenic activity, but smaller desmutagenic action, before the cyclophosphamide administration in mice. Thus, our study suggests that the co-administration of MEST and cyclophosphamide has pharmacokinetic interactions that potentiated the genotoxicity of cyclophosphamide, which contributed to the decrease in desmutagenic action.

According to the MEST phytochemical profile, the characteristics of concurrent treatment, MEST routes of administration, and cyclophosphamide, as well as the pre-mutagenic action of cyclophosphamide, compounds including tannins, quercetin, and biflavonoids that are present in MEST have induced hepatic metabolism (Oliveira and Dalla Costa, 2004), which increased the rate of formation of active metabolites of cyclophosphamide and favored the occurrence of genotoxic effects. This hypothesis could be confirmed by the antigenotoxicity that was observed in the simultaneous protocol that presented a DR\% of $22.61 \%$, which was significantly lower than that in the other protocols. However, despite the decrease in antigenotoxic action in the simultaneous protocol in mice, the antimutagenic effects were maintained with high rates; this confirms the ability of the MEST to repair genotoxic damage throughout the cell cycle and confer decreased mutagenic damage that occurred by the bioantimutagenic action of MEST.

The micronucleus test in all treatment protocols presented an increasing pattern of $\mathrm{DR} \%$ over $72 \mathrm{~h}$ of testing, with a trend of decreasing frequency of micronuclei over time. However, this same trend was not observed for the control and cyclophosphamide groups, where the frequency of micronuclei among T1, T2, and T3 samples was almost constant. This analysis minimizes the effects of metabolism and clearance of the alkylating agent in the decreased frequency of damage over time, and thus confirms the efficiency of MEST as an antimutagenic agent.

Comparing the chemopreventive action from the lowest concentration that was used in the $A$. cepa test $(16.8 \mathrm{mg} / \mathrm{L})$ and in mice $(16.8 \mathrm{mg} / \mathrm{kg})$ in the micronucleus assay, it is possible to verify the following according to the DR\%: (I) $91.18 \%$ of concordance for the posttreatment between the two tests, (II) $99.43 \%$ of concordance for the simultaneous treatment protocol, and (III) $56.11 \%$ of concordance for the pretreatment protocol between A. cepa and mice. The mode of action was characterized in a similar manner in both proposed assays, which confirms the use of the $A$. cepa test to suitably screen mutagenicity and antimutagenicity and to describe the mode of action of natural products; this also shows concordance that was higher than $80 \%$ between the tests that were performed with $A$. cepa and rodents (mice), as suggested by Rank and Nielsen (1997).

Considering the high value of total phenols and flavonoids that was found in MEST in this study and that $S$. terebinthifolius is essentially a tanniniferous plant, it is believed that these compounds and their derivatives (such as gallic acid) (Ceruks et al., 2007; Santana et al., 2012) have played an important antigenotoxic and antimutagenic role (Lira et al., 2008; Ben Sghaier et al., 2011; Santana et al., 2012). These phytochemicals can act as inhibitors 
of chemical carcinogenesis processes through antioxidant, anti-inflammatory, antimutagenic, and antitumor mechanisms of action including neutralizing free radicals, sequestering metal ions, gene expression modulation, inhibition of oxidative enzymes, and stimulation of antioxidant enzymes (Degáspari and Waszczynskyj, 2004; Lira et al., 2008; Ben Sghaier et al., 2011). Therefore, these biological activities confirm the desmutagenic and biomutagenic MEST mode of action that was observed in this study.

In conclusion, our results demonstrate the important chemopreventive activity of $S$. terebinthifolius, which is indirectly correlated with the prevention and/or treatment of degenerative diseases such as cancer. Our findings further indicate that $S$. terebinthifolius extract can prevent and/or repair the DNA damage that is caused by desmutagenesis and biomutagenesis and may therefore have therapeutic applications. This study also demonstrated that the $A$. cepa test is an important tool to screen and describe the antimutagenic mode of action of natural products. Currently, our research group is developing new phytochemical protocols to isolate the $S$. terebinthifolius compounds in order to test them individually to clarify the mechanisms of DNA interaction.

\section{ACKNOWLEDGMENTS}

Research supported by FUNDECT (Edital Chamada FUNDECT \#5/2011, PPP, Processo \#23/200.702/2012, Termo de Outorga \#0207/12; Edital Chamada FUNDECT/CNPq \#06/2011, PRONEM).

\section{Conflicts of interest}

The authors declare no conflict of interest.

\section{REFERENCES}

Antunes LMG and Araújo MCP (2000). Mutagenicidade e antimutagenicidade dos principais corantes para alimentos. $R$. Nutr. 13: 81-88.

Ben Sghaier M, Boubaker J, Skandrani I, Bouhlel I, et al. (2011). Antimutagenic, antigenotoxic and antioxidant activities of phenolic-enriched extracts from Teucrium ramosissimum: combination with their phytochemical composition. Environ. Toxicol. Pharmacol. 31: 220-232.

Brandão MGL, Consenza GP, Moreira RA and Monte-Mor RLM (2006). Medicinal plants and other botanical products from the Brazilian official pharmacopeia. Rev. Bras. Farmacogn. 16: 408-420.

Ceruks M, Romoff P, Fávero AO and Lago JHG (2007). Constituintes fenólicos polares de Schinus terebinthifolius Raddi (Anacardiaceae). Quím. Nova 30: 597-599.

Corrêa MP (1974). Dicionário de Plantas Úteis do Brasil e das Exóticas Cultivadas. Imprensa Nacional, Rio de Janeiro.

de Carvalho MC, Barca FN, Agnez-Lima LF and de Medeiros SR (2003). Evaluation of mutagenic activity in an extract of pepper tree stem bark (Schinus terebinthifolius Raddi). Environ. Mol. Mutagen. 42: 185-191.

de Carvalho NC, Correa-Angeloni MJ, Leffa DD, Moreira J, et al. (2011). Evaluation of the genotoxic and antigenotoxic potential of Melissa officinalis in mice. Genet. Mol. Biol. 34: 290-297.

de Mesquita ML, de Paula JE, Pessoa C, de Moraes MO, et al. (2009). Cytotoxic activity of Brazilian Cerrado plants used in traditional medicine against cancer cell lines. J. Ethnopharmacol. 123: 439-445.

De Flora S (1998). Mechanisms of inhibitors of mutagenesis and carcinogenesis. Mutat. Res. 402: 151-158.

Dearfield KL, Cimino MC, McCarroll NE, Mauer I, et al. (2002). Genotoxicity risk assessment: a proposed classification strategy. Mutat. Res. 521: 121-135.

Degáspari HC and Waszczynskyj N (2004). Propriedades Antioxidantes de Compostos Fenólicos. Visão Acadêmica, Curitiba. 
Djeridane A, Yousfi M, Nadjemi B and Boutassouna D (2006). Antioxidant activity of some algerian medicinal plants extracts containing phenolic compounds. Food Chem. 97: 654-660.

Fernandes TCC and Mazzeo DEC (2007). Mechanism of micronuclei formation in polyploidizated cells of Allium cepa exposed to trifluralin herbicide. Pesticide Biochem. Physiol. 88: 252-259.

Fiskesjö G (1993). The Allium test in wastewater monitoring. Environm. Toxicol. Water Qual. 8: 291-298.

Hayashi M, Morita T, Kodama Y, Sofuni T, et al. (1990). The micronucleus assay with mouse peripheral blood reticulocytes using acridine orange-coated slides. Mutat. Res. 245: 245-249.

Kada T and Shimoi K (1987). Desmutagens and bio-antimutagens-their modes of action. Bioessays 7: 113-116.

Kada T, Inoue T and Namiki N (1982). Environmental Desmutagens and Antidesmutagens. In: Environmental Mutagenesis, Carcinogenesis, and Plant Biology (Klekowski EJ, ed.). Praeger, New York, 137-151.

Kobayashi H, Sugiyama C, Morikawa Y and Hayashi M (1995). A comparison between manual microscopic analysis and computerized image analysis in the single cell gel electrophoresis assay. MMS Commun. 3: 103-115.

Leme DM and Marin-Morales MA (2009). Allium cepa test in environmental monitoring: a review on its application. Mutat. Res. 682: 71-81.

Lin JY and Tang CY (2007). Determination of total phenolic and flavonoid contents in selected fruits and vegetables, as well as their stimulatory effects on mouse splenocyte proliferation. Food Chem. 101: 140-147.

Lira WM, dos Santos FV, Sannomiya M, Rodrigues CM, et al. (2008). Modulatory effect of Byrsonima basiloba extracts on the mutagenicity of certain direct and indirect-acting mutagens in Salmonella typhimurium assays. J. Med. Food 11: 111-119.

Lucio Neto MP (2011). Avaliação Tóxica, Citotóxica, Genotóxica e Mutagênica do Composto3-(2-cloro-6-fluorobenzil)imidazolidina-2,4-diona em Células Eucarióticas. Master thesis, Universidade Federal do Piauí, Piauí.

Malini M, Marin-Morales MA, Mantovani MS, Jamal CM, et al. (2010). Determination of the antimutagenicity of an aqueous extract of Rhizophora mangle L. (Rhizophoraceae), using in vivo and in vitro test systems. Genet. Mol. Biol. 33: 176-181.

Manoharan K and Banerjee MR (1985). beta-carotene reduces sister chromatid exchanges induced by chemical carcinogens in mouse mammary cells in organ culture. Cell Biol. Int. Rep. 9: 783-789.

Martins de Oliveira J, Jordao BQ, Ribeiro LR, Ferreira da EA, et al. (2002). Anti-genotoxic effect of aqueous extracts of sun mushroom (Agaricus blazei Murill lineage 99/26) in mammalian cells in vitro. Food Chem. Toxicol. 40: 17751780.

Meda A, Lamien CE, Romito M and Millogo J (2005). Determination of the total phenolic, flavonoid and proline contents in burkina fasan honey, as well as their radical scavenging activity. Food Chem. 91: 571-577.

Morton JF (1978). Brazilian pepper - its impact on people, animals and the environment. Econ. Bot. 32: 353-359.

Oliveira AE and Dalla Costa T (2004). Interações farmacocinéticas entre as plantas medicinais Hypericum perforatum, Gingko biloba e Panax gingseng e fármacos tradicionais. Acta Farm. Bom. 23: 567-578.

Oliveira RJ, Ribeiro LR, da Silva AF, Matuo R, et al. (2006). Evaluation of antimutagenic activity and mechanisms of action of beta-glucan from barley, in CHO-k1 and HTC cell lines using the micronucleus test. Toxicol. In Vitro 20: 1225-1233.

Oliveira RJ, Matuo R, da Silva AF, Matiazi HJ, et al. (2007). Protective effect of beta-glucan extracted from Saccharomyces cerevisiae, against DNA damage and cytotoxicity in wild-type (k1) and repair-deficient (xrs5) CHO cells. Toxicol. In Vitro 21: 41-52.

Oliveira RJ, Baise E, Mauro MO, Pesarini JR, et al. (2009). Evaluation of chemopreventive activity of glutamine by the comet and the micronucleus assay in mice's peripheral blood. Environ. Toxicol. Pharmacol. 28: 120-124.

Queires LC, Fauvel-Lafetve F, Terry S, De la Taille A, et al. (2006). Polyphenols purified from the Brazilian aroeira plant (Schinus terebinthifolius, Raddi) induce apoptotic and autophagic cell death of DU145 cells. Anticancer Res. 26: 379-387.

Ramadan G, El-Beih NM and Zahra MM (2012). Egyptian sweet marjoram leaves protect against genotoxicity, immunosuppression and other complications induced by cyclophosphamide in albino rats. Br. J. Nutr. 108: 10591068.

Ramos Ruiz A, De la Torre RA, Alonso N, Villaescusa A, et al. (1996). Screening of medicinal plants for induction of somatic segregation activity in Aspergillus nidulans. J. Ethnopharmacol. 52: 123-127.

Rank J and Nielsen MH (1997). Allium cepa anaphase-telophase root tip chromosome aberration assay on N-methyl-Nnitrosourea, maleic hydrazide, sodium azide, and ethyl methanesulfonate. Mutat. Res. 390: 121-127.

Santana JS, Sartorelli P, Lago JHG and Matsuo AL (2012). Isolamento e avaliação do potencial citotóxico de derivados fenólicos de Schinus terebinthifolius Raddi (Anacardiaceae). Quím. Nova 35: 2245-2248.

Singh NP, McCoy MT, Tice RR and Schneider EL (1988). A simple technique for quantitation of low levels of DNA damage in individual cells. Exp. Cell Res. 175: 184-191. 
Varela-Barca FN, Agnez-Lima LF and de Medeiros SR (2007). Base excision repair pathway is involved in the repair of lesions generated by flavonoid-enriched fractions of pepper tree (Schinus terebinthifolius, Raddi) stem bark. Environ. Mol. Mutagen. 48: 672-681.

Waters MD, Brady AL, Stack HF and Brockman HE (1990). Antimutagenicity profiles for some model compounds. Mutat. Res. 238: 57-85.

WHO (2011). The World Medicines Situation: Traditional Medicines: Global Situation Issues and Challenges. World Health Organization, Geneva. 